\section{Effectiveness of Soil Salinity Management Practices in Basin-irrigated Pecan Orchards}

\author{
Seiichi Miyamoto ${ }^{1,3}$ and Monte Nesbitt ${ }^{2}$
}

ADDITIONAL INDEX WORDs. tillage, soil profile modification, drainage, root pruning

SUMMARY. Soil salinity management is a factor for successful production of pecan (Carya illinoinensis) in arid southwestern United States. An exploratory study was performed to evaluate the effect of various soil management practices on salt leaching in basin-irrigated orchards developed on alluvial soils (Torrifluvents, Entisols) of the middle Rio Grande Basin. The practices evaluated were ripping, minimum-till chiseling, and soil profile modification. For ripping, parabolic shanks were passed through the center section ( 4 to $8 \mathrm{ft}$ wide) between each tree row to a depth ranging from 18 to 36 inches. Minimum-till chisels included 7 - and 30-inch shanks, equipped with coulters to reduce break up of the ground surface. Soil profile modification consisted of trenching with a backhoe and profile mixing with a large excavator. The effectiveness of these methods was evaluated by measuring soil salinity and moisture in treated and untreated zones at 17 test sites. Both ripping and minimum-till deep chiseling helped improve salt leaching, and the effectiveness of salt leaching increased as working depths approach the thickness of the clayey layer. However, annual ripping of the center section of each tree row space may not provide wide enough zones to alleviate salt stress to the trees. Straight shanks prune but do not lift tree roots, thus appearing to be better suited for chiseling closer to tree rows. Soil profile modification was highly effective in leaching salts. From the view of minimizing soil aggregate destruction and of maintaining a leveled floor, minimum-till deep chiseling, followed by the use of sand-topdressing and minimum-till shallow chisels for maintenance may prove to be more desirable than conventional ripping, especially in soil types consisting of silty clay loam.

$\mathrm{P}$ ecan is among the most saltsensitive tree crops currently grown in the southwestern United States. The threshold soil salinity in the main root zone for tree growth appears to be around 2.0 $\mathrm{dS} \cdot \mathrm{m}^{-1}$ in the soil saturation extract when sodium $(\mathrm{Na})$ is the dominant cation (Fig. 1). Tree growth decreases after soil salinity exceeds the threshold, and it essentially ceases at soil salinity of 4 to $5 \mathrm{dS} \cdot \mathrm{m}^{-1}$ or $\mathrm{Na}$ concentrations of about $30 \mathrm{mmol} \cdot \mathrm{L}^{-1}$ in the soil saturation extract, and branch dieback begins at about 5 to $6 \mathrm{dS} \cdot \mathrm{m}^{-1}$ (or $50 \mathrm{mmol} \cdot \mathrm{L}^{-1}$ of $\mathrm{Na}$ ) or higher

The author also thanks several El Paso pecan growers for their cooperation and the Bureau of Reclamation, USDI, for the purchase of the minimum-till chisels. The work reported here was supported in part by the National Institute of Food and Agriculture, US Department of Agriculture under Agreement no. 2005-34461-15661, and the Hatch Project 4418 The preparation of this document was assisted by Yvette Pereyra and TiJeat Berry, student workers. Soil sampling, analyses, and data processing were assisted by Ignacio Martinez, Agricultural Research Worker, Mario Carbajal, and Carlos Varela.

${ }^{1}$ Professor and Soil Scientist, Texas AgriLife Research Center at El Paso, Texas A\&M University, 1380 A\&M Circle, El Paso, TX 79927.

${ }^{2}$ Extension Program Specialist, Texas AgriLife Extension Horticulture Sciences, Texas A\&M University, Mailstop 2134 College Station, TX 77843.

${ }^{3}$ Corresponding author. E-mail: s-miyamoto@tamu.edu.
(Miyamoto et al., 1986). High salinity also reduces shoot and leaf growth, nut size, and yields (Miyamoto et al., 1986). Although pecans are susceptible to acute effects of chloride $(\mathrm{Cl})$ ions, the long-term effect on tree growth is associated more often with $\mathrm{Na}$ (Miyamoto et al., 1985).

Neither salinity nor sodicity of the irrigation water from the Rio Grande is exceptionally high (Table 1). In fact, salt-sensitive crops have been grown successfully in the Mesilla Valley located above the El Paso Valley. Quality of groundwater in the upper reach is usually as good as the river water, and the level of salt accumulation is only modest, 2 to $3.5 \mathrm{dS} \cdot \mathrm{m}^{-1}$ in the saturation extract, except in limited cases (Picchioni et al., 2000). In the El Paso Valley, reclaimed municipal effluent
(Table 1), returnflow, and/or salty groundwater are blended into the river water, especially during drought years, thus raising salinity of the irrigation water and irrigated soils. Salts often accumulate in clayey soils, which have low permeability (Miyamoto and Cruz, 1986). Figure 2 illustrates the typical profile of soil types in the study area, which are prone to soil salinization. Salinization is usually pronounced in deep silty clay and has been reported even in field crop production involving annual chiseling and plowing (Miyamoto and Cruz, 1987). Soil salinization is potentially exacerbated in orchard soils, mainly as a result of soil compaction imposed by equipment traffic. Soil compaction reduces soil permeability as well as root growth (Shafiq et al., 1994; Sillon et al., 2003) and can reach as deep as $3 \mathrm{ft}$ under high axle load (Håkansson and Reeder, 1994). Experienced growers recognize the need to minimize salt accumulation in clayey portions, especially during or after the temporary use of saline groundwater.

There are two basic approaches in reducing salt accumulation. One is to apply an ample amount of water at each irrigation for salt leaching, usually using the steady-state salt balance equation as a guide (e.g., Rhoades, 1974). While this approach is conceptually valid, it is unlikely to leach salts from the clayey portion unless low permeability is improved. Otherwise, irrigation water applied to a basin percolates preferentially through permeable portions of the basin (Miyamoto, 1990). The use of control borders to hold ponded water in place can help, but is rarely practiced as water stands in the clayey portion for an extended period. Pecan trees cannot tolerate standing water during summer months (e.g., Kallestad et al., 2007).

Another approach is to improve permeability and drainage in the clayey portion of the basin. Various methods

\begin{tabular}{llll}
\hline $\begin{array}{l}\text { Units } \\
\begin{array}{l}\text { To convert U.S. to SI, } \\
\text { multiply by }\end{array}\end{array}$ & U.S. unit & SI unit & $\begin{array}{l}\text { To convert SI to U.S., } \\
\text { multiply by }\end{array}$ \\
\hline $\mathrm{l}$ & $\%$ & $\mathrm{~g} / \mathrm{l} 00 \mathrm{~g}$ & $\mathrm{l}$ \\
0.3048 & $\mathrm{ft}$ & $\mathrm{m}$ & 3.2808 \\
2.54 & inch $(\mathrm{es})$ & $\mathrm{cm}$ & 0.3937 \\
25.4 & inch $(\mathrm{es})$ & $\mathrm{mm}$ & 0.0394 \\
1.6093 & mile(s) & $\mathrm{km}$ & 0.6214 \\
1 & mmho/cm & $\mathrm{dS} \cdot \mathrm{m}^{-1}$ & 1 \\
1 & $\mathrm{ppm}$ & $\mathrm{mg} \cdot \mathrm{L}^{-1}$ & 1
\end{tabular}




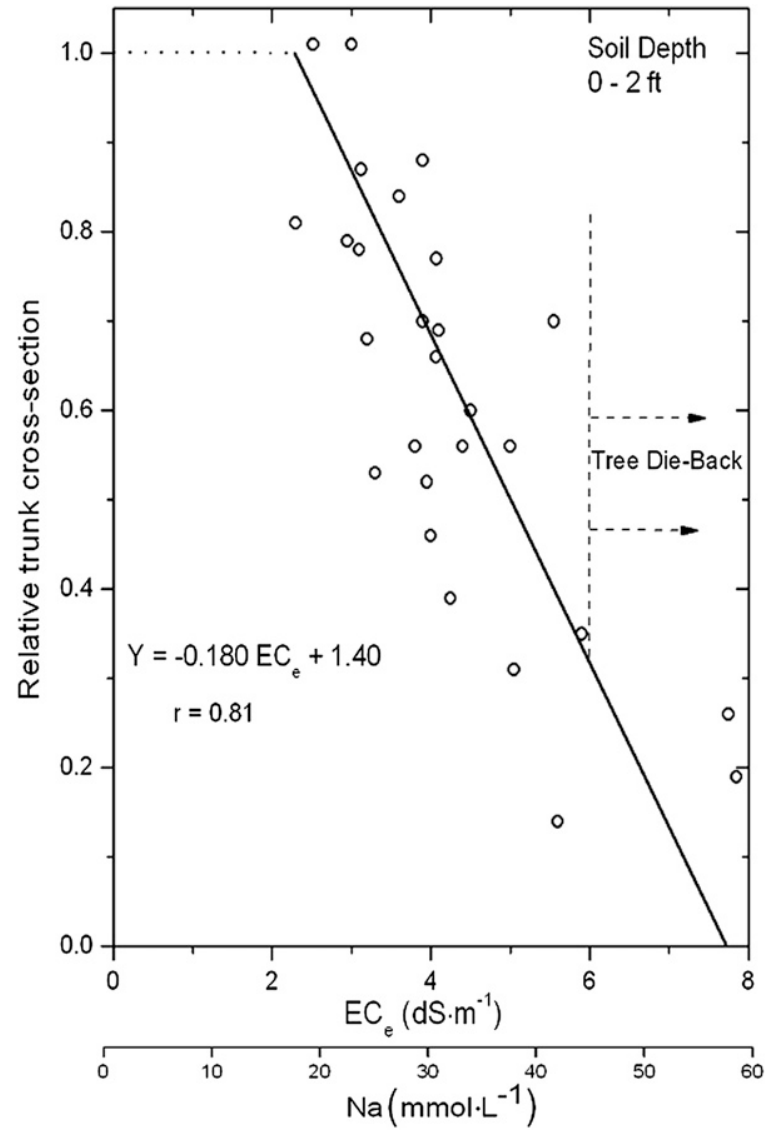

Fig. 1. The relative trunk cross-section of pecan trees relative to those of the same age grown under no salt stress as related to the EC of the soil saturation extract $\left(\mathrm{EC}_{\mathrm{e}}\right)$, in the main root zone depth of 0-24 inches (Miyamoto et al., 1986); 1 inch = $2.54 \mathrm{~cm}, 1 \mathrm{dS} \cdot \mathrm{m}^{-1}=1 \mathrm{mmho} / \mathrm{cm}, 1 \mathrm{mmol} \cdot \mathrm{L}^{-1} \operatorname{sodium~}(\mathrm{Na})=22.9898 \mathrm{ppm} \mathrm{Na}$.
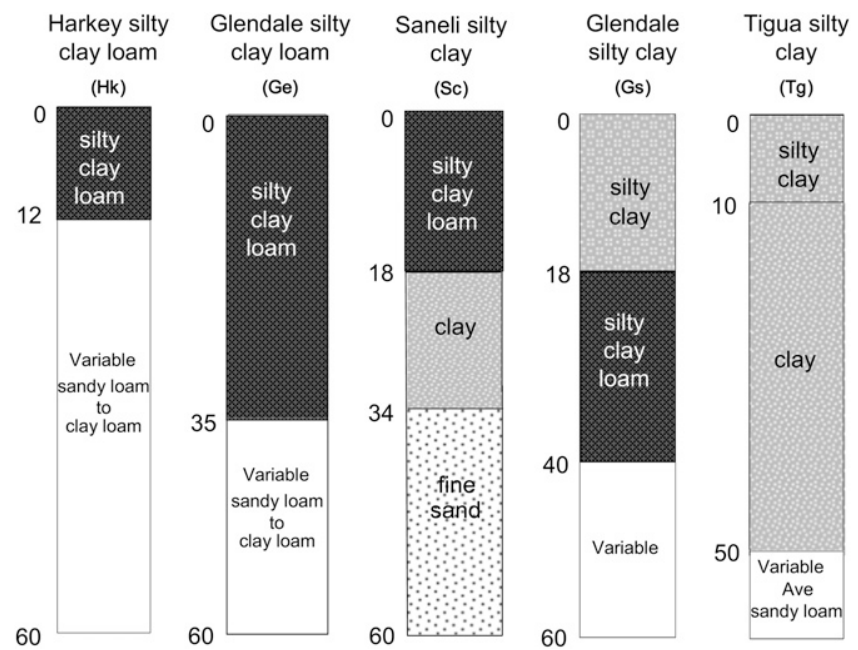

Fig. 2. Typical soil profiles (in inches of depth) of the soil types prone to salinization in the pecan study area (U.S. Department of Agriculture and Texas Agricultural Experiment Station, 1971); 1 inch $=2.54 \mathrm{~cm}$.

are used to improve permeability and include ripping, subsoiling, slip plowing, soil profile modification, and chemical amendments (e.g., Miyamoto and Storey, 1995; Wildman et al.,
1988). Ripping employs parabolic shanks to break up the soil to various depths, whereas subsoiling with straight shanks creates soil cracks without ripping the ground surface. Slip plowing, also a form of subsoiling, was once used extensively for row crop production, especially in California (Kaddah, 1976; Robinson and Luthin, 1968), but seldom in pecan orchards. Sodded floor management has also been reported to improve soil permeability (e.g., Folorunso et al., 1992; Prichard et al., 1990). However, the data needed to evaluate the effectiveness of these methods for leaching salt in pecan orchards are limited, except for ripping (Helmers and Miyamoto, 1990). The present study was conducted to determine the effectiveness of various management practices for lowering soil salinity in basin-irrigated pecan orchards established on alluvial soils. Results, largely exploratory, may be useful for developing soil management strategy in basin-irrigated orchards with similar soil characteristics.

\section{Test sites and methods}

Five orchards located within a 12-mile distance in the Lower El Paso Valley, TX, were examined for this study (Table 2). The primary consideration for selecting test orchards was to cover a broad range of soil types and soil management practices. An additional consideration was to include trees with leaf-tip burn. The extent of leaf-tip burn (a salt-stress indicator) was observed by measuring the length of browned tips in Oct. 2010, using 10 middle leaflets per tree (Table 2). Included in Table 2 is the tree trunk size measured at $2 \mathrm{ft}$ above the ground, using five to six trees per soil sampling site.

The orchards examined were planted with 'Western Schley' at various time periods, laser-leveled, and irrigated using large basin methods with high flow gates. The irrigation water used came from the Rio Grande (Table 1). Orchard E and, to a lesser extent, Orchard B blended saline groundwater ( 3 to $4 \mathrm{dS} \cdot \mathrm{m}^{-1}$ ) into the river water to supplement the shortfall. Orchard E has also used reclaimed water and returnflow mainly during fall and winter months for leaching salts. Reclaimed water has elevated sodicity (Table 1 ) and was treated on-site with sulfuric acid (Miyamoto and Storey, 1995). The area studied has the network of open drains, and the water table ranged from 6 to $9 \mathrm{ft}$ deep during summer months and falls during the nonirrigation season.

Mature trees in the study area are typically basin-irrigated once per 
Table 1. The mean concentrations of dissolved salts in the middle Rio Grande at American Dam and reclaimed municipal effluent, both reported monthly during 2009 and $2010 .^{\mathrm{z}}$

\begin{tabular}{|c|c|c|c|c|c|c|c|}
\hline Water sources & $\begin{array}{c}\mathrm{EC} \\
\left(\mathrm{dS} \cdot \mathrm{m}^{-1}\right)^{\mathrm{y}}\end{array}$ & $\begin{array}{c}\text { TDS } \\
\left(\mathrm{mg} \cdot \mathrm{L}^{-1}\right)^{\mathrm{y}}\end{array}$ & SAR $^{y}$ & $\begin{array}{l}\text { Sodium } \\
\left(\mathrm{mg} \cdot \mathrm{L}^{-1}\right)\end{array}$ & $\begin{array}{l}\text { Calcium } \\
\left(\mathrm{mg} \cdot \mathrm{L}^{-1}\right)\end{array}$ & $\begin{array}{l}\text { Magnesium } \\
\left(\mathrm{mg} \cdot \mathrm{L}^{-1}\right)\end{array}$ & $\begin{array}{l}\text { Chlorine } \\
\left(\mathrm{mg} \cdot \mathrm{L}^{-1}\right)\end{array}$ \\
\hline \multicolumn{8}{|c|}{ Rio Grande (El Paso, TX $)^{z}$} \\
\hline Winter (returnflow) & 2.3 & 1440 & 9.1 & 332 & 117 & 27 & 280 \\
\hline \multicolumn{8}{|l|}{ Reclaimed effluent } \\
\hline Northwest plant & 2.1 & 1120 & 9.8 & 350 & 45 & 5 & 325 \\
\hline
\end{tabular}

${ }^{2}$ Rio Grande at the entry into El Paso, TX, in 2009 and 2010. Water salinity in the Lower El Paso Valley is higher by 50 to $200 \mathrm{mg} \mathrm{L}^{-1}$ due to blending of reclaimed effluent and/ or return flow.

${ }^{y} \mathrm{EC}=$ electrical conductivity, $\mathrm{TDS}=$ total dissolved salts, $\mathrm{SAR}=$ sodium absorption ratio; $1 \mathrm{dS} \cdot \mathrm{m}^{-1}=1 \mathrm{mmho} / \mathrm{cm}, 1 \mathrm{mg} \cdot \mathrm{L}^{-1}=1 \mathrm{ppm}$.

Table 2. Soil types, tree trunk sizes, leaflet sizes, leaf injury, and floor management practices used at the pecan test orchards.

\begin{tabular}{|c|c|c|c|c|c|c|c|c|c|}
\hline $\begin{array}{l}\text { Orchard } \\
\text { code }\end{array}$ & $\begin{array}{l}\text { Site } \\
\text { code }\end{array}$ & $\begin{array}{l}\text { Soil } \\
\text { type }^{z}\end{array}$ & $\begin{array}{c}\text { Tree age } \\
\text { (years) }\end{array}$ & $\begin{array}{c}\text { Tree space } \\
(\mathrm{ft} \times \mathrm{ft})^{\mathrm{y}}\end{array}$ & $\begin{array}{c}\text { Trunk } \\
\text { diam } \\
\text { (inches) }^{y}\end{array}$ & $\begin{array}{l}\text { Leaflet } \\
\text { length } \\
\text { (inches) }^{\mathrm{y}}\end{array}$ & $\begin{array}{c}\text { Leaf } \\
\text { injury }^{x}\end{array}$ & $\begin{array}{l}\text { Soil salinity } \\
\left(\mathrm{dS} \cdot \mathrm{m}^{-1}\right)^{\mathrm{w}}\end{array}$ & $\begin{array}{c}\text { Floor } \\
\text { management }\end{array}$ \\
\hline A & 1 & $\mathrm{Ha}$ & 32 & $32 \times 34$ & 15 & - & - & 2.3 & Clean, disk \\
\hline B & 2 & Gs & 37 & $32 \times 36$ & 8 & 3.4 & M & 3.5 & Grass, ripping \\
\hline $\mathrm{C}$ & 1 & $\mathrm{Ha}$ & 48 & $32 \times 32$ & 14 & - & - & 3.2 & Grass, herbicide \\
\hline \multirow[t]{3}{*}{$\mathrm{D}$} & 352 & $\mathrm{Hk}$ & 43 & $32 \times 32$ & 15 & 3.4 & $\mathrm{~L}$ & 1.9 & Clean, MTSC ${ }^{\mathrm{v}}$, ripping \\
\hline & 372 & $\mathrm{Ge}$ & 43 & $32 \times 32$ & 12 & 3.0 & $\mathrm{H}$ & 4.9 & Clean, MTSC, ripping \\
\hline & 133 & $\mathrm{Tg}$ & 17 & $17 \times 34$ & 6 & 3.0 & M & 4.0 & Clean, MTSC, ripping \\
\hline \multirow[t]{3}{*}{$\mathrm{E}$} & 29 & $\mathrm{Ge}$ & 13 & $30 \times 30$ & 8 & 3.6 & M & 2.7 & Grass and herbicide \\
\hline & 55 & Sc & 52 & $34 \times 54$ & 8 & 3.6 & $\mathrm{H}$ & 4.1 & Grass and herbicide \\
\hline & 552 & $\mathrm{Tg}$ & 50 & $30 \times 46$ & 11 & 3.1 & M & 2.6 & Grass and herbicide \\
\hline
\end{tabular}

${ }^{\mathrm{z}}$ For soil profile identification, refer to Fig. 2 ; $\mathrm{Ha}$ is similar to $\mathrm{Hk}$.

${ }^{y} \mathrm{l} \mathrm{ft}=0.3048 \mathrm{~m}, 1$ inch $=2.54 \mathrm{~cm}$.

${ }^{x}$ Leaf-tip burn as percent of leaflet length: $\mathrm{L}=$ low ( $\left.<5 \%\right), \mathrm{M}=$ medium ( $5 \%$ to $\left.10 \%\right), \mathrm{H}=$ high ( $\left.>10 \%\right)$.

"Salinity of the saturation extract made from 0 to $2 \mathrm{ft}$ from untreated zones; $1 \mathrm{dS} \cdot \mathrm{m}^{-1}=1 \mathrm{mmho} / \mathrm{cm}$.

${ }^{\vee}$ MTSC = minimum-till surface chisel.

month during March through May and twice a month during June through September with a season total of 11 to 12 irrigations. A typical irrigation depth is 4 inches per application, except for the first irrigation. However, Orchard B, consisting of Glendale soil series, has used 6 inches of irrigation every 3 weeks during summer months. Orchard E was irrigated at less than 2 -week intervals and has practiced offseason irrigation. The main root zone of pecan trees in this valley is rather shallow, typically ranging from 18 to 36 inches (Miyamoto, 1983).

Floor management practices varied with orchards. Orchard A used clean cultivation using a ripper and a cultivator. The ripping operation was performed in one direction at two sites using three shanks spaced 40 inches apart at a width of $7 \mathrm{ft}$ to a depth of 18 inches. The first site consisting of Harkey loam ( $\mathrm{Ha}$ ) had no history of ripping, and the second site on Glendale silty clay loam (Ge) had been ripped once per year. Ripping was followed by a cultivator (8-inch deep, five shanks spaced 12 inches apart equipped with a spike roll to break clods) in both directions throughout the orchard floor. This orchard had been irrigated with river water, supplemented with well water of low salinity $\left(1.4 \mathrm{dS} \cdot \mathrm{m}^{-1}\right)$ as needed.

Orchard B had initially adopted clean cultivation using a ripper and a disk and then was converted to mowed floor management for 5 to 6 years until 2003. Well water with elevated salinity (conductivity of 3.4 $\mathrm{dS} \cdot \mathrm{m}^{-1}$ ) was used during the drought of 2003, resulting in significant salt damage, including tree dieback. Soil profile modification was then implemented in every other tree row in the center $12 \mathrm{ft}$ to a depth twice the thickness of the clay layer 3 years before soil sampling. Unexcavated rows were ripped using five shanks 
spaced 15 inches in one pass covering a 7 -ft strip in the center to a depth of 36 inches. The entire floor was then disked in two directions and leveled.

Orchard C used a cultivator and a mower in the center and herbicide along the tree rows to control floor vegetation. In 2004, a minimum-till shallow chisel (MTSC) equipped with 8 -inch shanks spaced 15 inches apart was introduced (Fig. 3A). The chisel was used in one direction, two passes covering a total of $18 \mathrm{ft}$, once in April, then in June to a depth of 7 inches. Soil samples were collected in July from three zones: chiseled, mowed, and herbicide-treated strips.

Orchard D used a disk to control floor vegetation and ripping in the center to a depth of 17 inches since planting. The MTSC was introduced in 2004 and has been used in the center 18-ft strip in one direction with two passes after each irrigation until June. In 2008 (2 years before sampling), the ripper was replaced with deeper curved shanks; a set of five shanks spaced 20 inches apart. The ripper was passed once in one direction at $6 \mathrm{ft}$ wide to a depth of 36 inches at the beginning of each irrigation season. In some blocks of Orchard D, the projected tree rows were trenched before tree planting 16 to 17 years ago, $9 \mathrm{ft}$ wide every $34 \mathrm{ft}$ to a depth sufficient to mix the two layers at a $1: 1$ ratio. Trees were then planted along the center of the trenches at a spacing of $17 \mathrm{ft}$ to form hedge rows. The area that was not trenched was chiseled with the MTSC in two passes in one direction (18 ft wide) and with the ripper along the middle $(7 \mathrm{ft}$ wide to a depth of 36 inches).

Orchard E used a mower to control vegetation for many years. After the drought of 2003 , minimum-till deep chiseling was introduced as a means to break up the compacted floor. The equipment with a four-shank
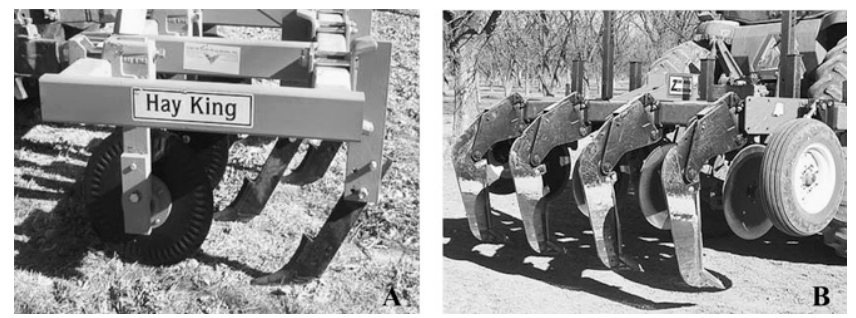

Fig. 3. (A) Minimum-till surface chisel and (B) deep-shank, both equipped with coulters.

assembly (Fig. 3B) with a width of $9 \mathrm{ft}$ was pulled by a 250 -horsepower tractor in two passes at a total width of $18 \mathrm{ft}$ between tree rows, leaving 7 to $8 \mathrm{ft}$ to the tree trunks in Mar. 2008. It was followed by topdressing with dry loamy sand to a depth of about 1 inch. (Loamy sand is locally available along the edge of the floodplains or below the clay layer.) The dry sand filled soil cracks, which measure up to $3 / 4$ inch wide, and covered the ground lightly. Soil samples were collected from unchiseled and chiseled zones 2 to 3 years later.

Soil samples from three depths $(0-1,1-2$, and $2-3 \mathrm{ft})$ were collected at five to six holes per soil type per treated and untreated zones. According to a previous study (Miyamoto and Cruz, 1986), salinity of soil samples collected in this manner is expected to yield the mean value with a deviate range of $15 \%$ from the true mean. Soil samples collected were airdried, passed through a $2-\mathrm{mm}$ screen, and the saturated paste was prepared as described in Rhoades and Miyamoto (1990). The moisture content of the saturated paste and salinity of the saturation extract were determined gravimetrically and with an EC meter, respectively. The effect of soil treatments on these properties was assessed with the split-plot analysis of variance, using the depth as the main plot and the soil treatment as the subplot (Little and Hills, 1975), followed by the Duncan's multiple range test at a $5 \%$ level.

\section{Results and discussion}

RIPPING. The use of 18-inch ripper in Harkey loam $(\mathrm{Ha})$ section of Orchard A resulted in a significant reduction in soil salinity in the ripped zone, especially at a depth of $1-2 \mathrm{ft}$ where salts had been accumulated to the level of $4.8 \mathrm{dS} \cdot \mathrm{m}^{-1}$ (Table 3 ). Soil salinity readings below $2 \mathrm{ft}$ were lower than at $1-2 \mathrm{ft}$, as a result of oversaturation, which occurs in loamy sand. The ripping operation also resulted in significantly higher field soil water contents (Table 3). Annual ripping of Glendale silty clay loam $(\mathrm{Ge})$ at the second site in Orchard A caused nearly complete leaching of salts from the ripped zone (Table 3 ). However, the soil moisture content below $\mathrm{l} \mathrm{ft}$ was lower in ripped zones, probably as a result of a greater degree of water uptake by the roots, which branched out because of repeated root pruning over the years. Soil salinity of the ripped area was also significantly lower in Glendale silty clay (Gs) section of Orchard B, as reported in Helmers and Miyamoto (1990). Additional data on soil ripping effects on soil salinity are shown in Tables 5-8.

These data show that ripping promotes salt leaching where implemented. However, annual ripping along the middle of row space did not seem to alleviate salt stress to the trees. Although soil salinity decreased to as low as $1.5 \mathrm{dS} \cdot \mathrm{m}^{-1}$ in the ripped zone, leaf injury at Orchard A, for example, remained at an elevated level. Likewise, ripping at Orchard D lowered soil salinity significantly, but leaf-tip burn remained high, especially at Sites 351 and 5 . The trees seem to be responding to salinity of the unripped zones, as the ripped zone accounts for a small proportion, usually less than $1 / 4$ of the orchard floor, and roots are cut every year.

Minimum-till chiseling. Salinity of soil samples collected from chiseled, sodded, and herbicidetreated zones in Orchard $\mathrm{C}$ is shown in Table 4. Chiseling was made with the MTSC twice before sampling. There was no significant effect of chiseling on soil salinity at the first depth, but it did lower it at the depths below. The use of the chisel may have helped improve water penetration. Unfortunately, field soil moisture data were not available at this site.

The MTSC used in combination with deep ripping (36-inches deep) at Orchard D did not lower soil salinity, but deep ripping did at the sites consisting of deep clayey soils (Table 5). At Harkey silty clay loam ( $\mathrm{Hk}$ ) site, there was no significant impact of soil treatments on either soil salinity or soil moisture levels. Although the MTSC did not significantly lower soil salinity, the soil moisture level in the chiseled 
Table 3. The saturation water content (SWC), soil salinity, and field soil moisture content in ripped and unripped (control) zones at pecan Orchards A and B. ${ }^{\mathrm{z}}$

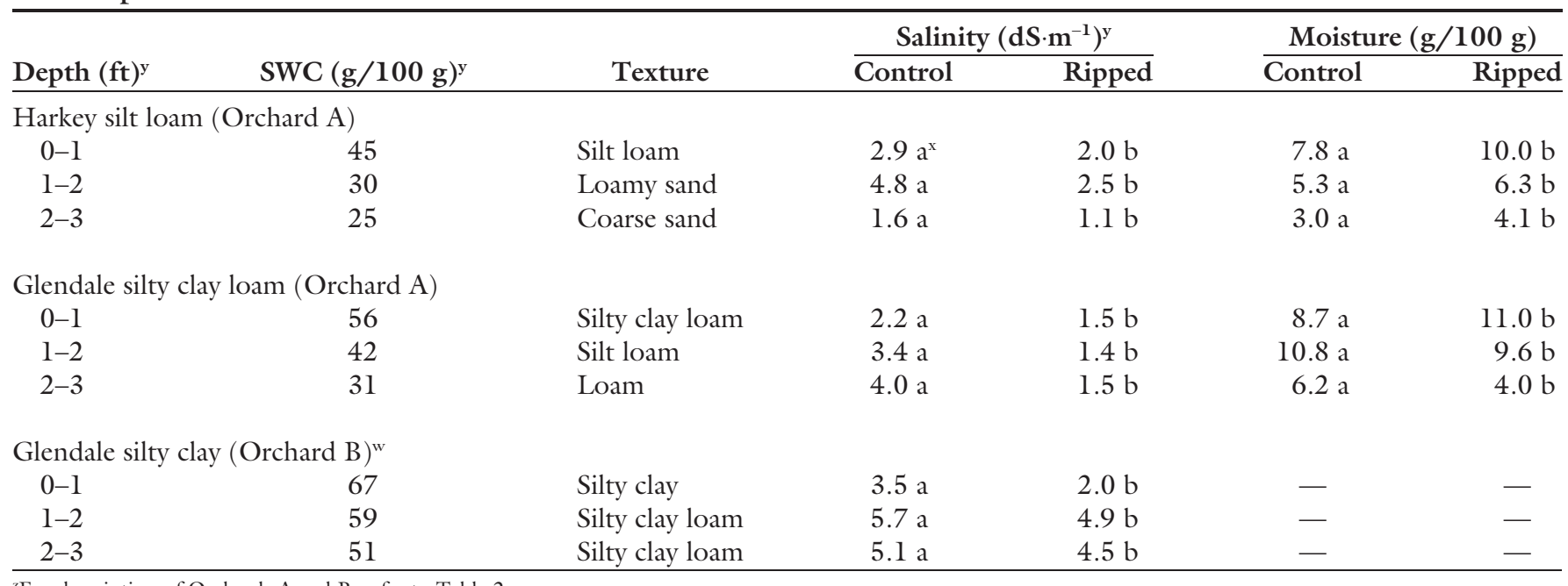

${ }^{\mathrm{z}}$ For description of Orchards $\mathrm{A}$ and $\mathrm{B}$, refer to Table 2 .

${ }^{y} 1 \mathrm{ft}=0.3048 \mathrm{~m}, \mathrm{lg} / \mathrm{l} 00 \mathrm{~g}=1 \%, \mathrm{ldS} \cdot \mathrm{m}^{-1}=1 \mathrm{mmho} / \mathrm{cm}$.

${ }^{x}$ Numbers in row followed by the same letter in each parameter are not significantly different via Duncan's multiple range test at $P \leq 0.05$.

weported by Helmers and Miyamoto (1990).

Table 4. The saturation water content (SWC), soil salinity in surface-chiseled, mowed, and herbicide-treated zones at pecan Orchard C. ${ }^{\mathrm{z}}$

\begin{tabular}{|c|c|c|c|c|c|}
\hline \multirow[b]{2}{*}{ Depth $(\mathrm{ft})^{\mathrm{y}}$} & \multirow[b]{2}{*}{ Texture } & \multirow{2}{*}{$\begin{array}{c}\text { SWC } \\
(\mathrm{g} / 100 \mathrm{~g})^{\mathrm{y}}\end{array}$} & \multicolumn{3}{|c|}{ Salinity $\left(\mathrm{d} S \cdot \mathrm{m}^{-1}\right)^{\mathrm{y}}$} \\
\hline & & & Chiseled & Mowed & Herbicide \\
\hline \multicolumn{6}{|c|}{ Harkey silt loam (Ha) } \\
\hline $0-1$ & Silt loam & 55 & $2.4 \mathrm{a}^{\mathrm{x}}$ & $2.4 \mathrm{a}$ & $2.3 \mathrm{a}$ \\
\hline $1-2$ & Silt loam & 46 & $4.0 \mathrm{a}$ & $4.8 \mathrm{~b}$ & $5.2 \mathrm{~b}$ \\
\hline $2-3$ & Loamy sand & 31 & $4.2 \mathrm{a}$ & $6.2 \mathrm{~b}$ & $8.8 \mathrm{c}$ \\
\hline
\end{tabular}

${ }^{\mathrm{z}}$ For description of Orchard C, refer to Table 2.

${ }^{\mathrm{y}} 1 \mathrm{ft}=0.3048 \mathrm{~m}, \mathrm{lg} / 100 \mathrm{~g}=1 \%, 1 \mathrm{dS} \cdot \mathrm{m}^{-1}=1 \mathrm{mmho} / \mathrm{cm}$.

${ }^{x}$ Numbers in rows followed by the same letter are not significantly different via Duncan's multiple range test at $P \leq 0.05$

zone was comparable to the ripped zone. This observation may indicate that irrigation water has infiltrated in the chiseled zones, but not deep enough to cause adequate salt leaching. It is uncertain whether annual ripping helped reduce salt stress or actually accentuated the problem by letting irrigation water to leak through the ripped strip where roots are cut annually. The salt-stress indicator remained high, especially at Sites 351 and 5 of Orchard D (Table 2).

The minimum-till deep chisel (MTDC) (using 30-inch shanks) caused a major reduction in soil salinity when tested in the Glendale silty clay loam section of Orchard E, but had no impact on field soil water contents (Table 6). The test field was irrigated in October, about 2 weeks before soil sampling, and the field was wet when sampled. The saturation water content of the surface $1 \mathrm{ft}$ was lower than that of the depth below, as a result of topdressing with sand in both chiseled and nonchisled areas. The MTDC also reduced salinity in Saneli silty clay loam at Site 55 , but not to the same degree as it did in Glendale silty clay loam (Table 6). Note that Saneli silty clay loam, but not Glendale, has an expandable clay layer below 18 inches (Fig. 2), thus making it difficult to leach. The soil moisture data indicate higher soil moisture contents below $1 \mathrm{ft}$, as compared with those unchiseled zones (Table 6). In Tigua silty clay, which has a deep clay layer (Fig. 2), chiseling did not lower soil salinity as it was already low because of prior excavation. Nonetheless, the saturation water content remained high at Tigua site, indicating that the site was deep-plowed, but probably did not reach the loamy sand layer below. In deep silty clay soils, the MTDC probably needs to be combined with either trenching or deep subsoiling to assure drainage.

Leaf injury remained at a moderate level at Site 29 of Orchard E consisting of Glendale silty clay loam even though soil salinity in the chiseled zone decreased to as low as $1.0 \mathrm{dS} \cdot \mathrm{m}^{-1}$ (Table 2). The area chiseled accounts for nearly two-thirds of the orchard floor, and the grower reported visible improvements in tree growth along with water infiltration. It is yet to be seen if salt stress will decrease to a low level with time as the roots reestablish themselves in the chiseled area with low salinity. Leaves at Site 552 consisting of Tigua silty clay have also shown some yellowing, a symptom common in wet soils.

SOIL PROFILE MODIFICATION. Soil profile modification conducted 2 to 3 years before soil sampling at Orchard $B$ caused a significant reduction in soil salinity in all cases tested (Table 7). (The data for Site 2 were similar to Site 16 and are omitted for simplicity.) Ripping with the 20 -inch curved shanks also helped reduce salinity although not to the same extent as achieved by soil profile modification. The saturation water content has also decreased from $60-70$ to $35-45 \mathrm{~g} /$ $100 \mathrm{~g}$, which corresponded to that of silty clay and silt loam, respectively. The soil salinity data obtained as a function of distance from the end of the excavated strip showed no reduction in salinity with the distance, starting at the first sampling site, which was $3 \mathrm{ft}$ away from the edge of excavation. This finding is consistent with an earlier report that the effect of trenching on salt leaching 
Table 5. The saturation water content (SWC), soil salinity, and field soil moisture contents of soil samples collected from unchiseled (control), deep-ripped strips (Rip), and minimum-till surface chiseled (MTSC) zones at pecan Orchard D. ${ }^{\mathrm{z}}$

\begin{tabular}{|c|c|c|c|c|c|c|c|c|}
\hline \multirow[b]{2}{*}{ Depth $(\mathrm{ft})^{\mathrm{y}}$} & \multirow[b]{2}{*}{ Texture } & \multirow[b]{2}{*}{$\operatorname{SWC}(\mathrm{g} / 100 \mathrm{~g})^{\mathrm{y}}$} & \multicolumn{3}{|c|}{ Salinity $\left(\mathrm{d} S \cdot \mathrm{m}^{-1}\right)^{\mathrm{y}}$} & \multicolumn{3}{|c|}{ Field moisture (g/100 g) } \\
\hline & & & Control & MTSC & Rip & Control & MTSC & Rip \\
\hline \multicolumn{9}{|c|}{ Harkey silty clay loam $(\mathrm{Hk})$, Site $352^{\mathrm{x}}$} \\
\hline $1-2$ & Silty clay loam & 40 & 1.5 & 1.4 & 1.1 & 7 & 11 & 7 \\
\hline $2-3$ & Loam & 32 & 1.5 & 1.9 & 0.6 & 5 & 6 & 4 \\
\hline $1-2$ & Silty clay loam & 57 & $6.2 \mathrm{a}$ & $6.2 \mathrm{a}$ & $3.4 \mathrm{~b}$ & $18 \mathrm{a}$ & $18 \mathrm{a}$ & $20 \mathrm{~b}$ \\
\hline $2-3$ & Silty clay loam & 47 & $5.5 \mathrm{a}$ & $5.6 \mathrm{a}$ & $5.6 \mathrm{a}$ & $16 \mathrm{a}$ & $14 \mathrm{a}$ & $20 \mathrm{~b}$ \\
\hline \multicolumn{9}{|c|}{ Glendale silty clay (Gs), Site 5} \\
\hline $0-1$ & Silty clay & 57 & $5.2 \mathrm{a}$ & $4.0 \mathrm{~b}$ & $3.2 \mathrm{c}$ & $7 \mathrm{a}$ & $10 \mathrm{~b}$ & $11 \mathrm{~b}$ \\
\hline
\end{tabular}

${ }^{2}$ For description of Orchard D, refer to Table 2 .

${ }^{y} l \mathrm{ft}=0.3048 \mathrm{~m}, \mathrm{lg} / 100 \mathrm{~g}=1 \%, \mathrm{l} \mathrm{dS} \cdot \mathrm{m}^{-1}=1 \mathrm{mmho} / \mathrm{cm}$.

${ }^{x}$ No mean separation is given as analysis of variance shows insignificant response.

"Data from Site 372 were similar to Site 351 and are omitted for simplicity.

"Numbers in rows followed by the same letter are not significantly different via Duncan's multiple range test at $P \leq 0.05$.

Table 6. The saturation water content (SWC), soil salinity, and field moisture contents in chiseled zone with the minimum-till deep chisel (MTDC) and unchiseled zones (control) at pecan Orchard E. ${ }^{z}$

\begin{tabular}{|c|c|c|c|c|c|c|}
\hline \multirow[b]{2}{*}{ Depth $(\mathrm{ft})^{\mathrm{y}}$} & \multirow[b]{2}{*}{$\operatorname{SWC}(\mathrm{g} / 100 \mathrm{~g})^{\mathrm{y}}$} & \multirow[b]{2}{*}{ Texture } & \multicolumn{2}{|c|}{ Soil salinity $\left(\mathrm{dS} \cdot \mathrm{m}^{-1}\right)^{\mathrm{y}}$} & \multicolumn{2}{|c|}{ Moisture (g/100 g) } \\
\hline & & & Control & MTDC & Control & MTDC \\
\hline \multicolumn{7}{|c|}{ Glendale silty clay loam (Ge), Site 29} \\
\hline $1-2$ & 60 & Silty clay loam & $2.9 \mathrm{a}$ & $1.1 \mathrm{~b}$ & $25 \mathrm{a}$ & $27 \mathrm{a}$ \\
\hline $2-3$ & 62 & Silty clay loam & $3.9 \mathrm{a}$ & $1.0 \mathrm{~b}$ & $26 a$ & $26 a$ \\
\hline $1-2$ & 75 & Clay & $5.5 \mathrm{a}$ & $3.4 \mathrm{~b}$ & $18 \mathrm{a}$ & $28 \mathrm{~b}$ \\
\hline $2-3$ & 72 & Clay & $5.6 \mathrm{a}$ & $4.8 \mathrm{~b}$ & $17 \mathrm{a}$ & $22 \mathrm{~b}$ \\
\hline \multicolumn{7}{|c|}{ Tigua silty clay (Tg excavated), Site 552} \\
\hline $0-1$ & 61 & Silty clay & $1.7 \mathrm{a}$ & $1.9 \mathrm{a}$ & $17 \mathrm{a}$ & $16 \mathrm{a}$ \\
\hline
\end{tabular}

${ }^{z}$ For description of Orchard E, refer to Table 2 .

${ }^{\mathrm{y}} \mathrm{lft}=0.3048 \mathrm{~m}, \mathrm{lg} / 100 \mathrm{~g}=1 \%, \mathrm{ldS} \cdot \mathrm{m}^{-1}=1 \mathrm{mmho} / \mathrm{cm}$

${ }^{x}$ Numbers in rows followed by the same letter are not significantly different via Duncan's multiple range test at $P \leq 0.05$

is essentially confined within the trench (Miyamoto and Storey, 1995).

According to the irrigation supervisor of orchard $\mathrm{B}$, no change in irrigation scheduling ( 6 inches of irrigation every 3 weeks) was made after profile modification. The site observations indicate that the middle of the excavated strips has settled by as much as 1 to 2 inches. It is possible that salt leaching in the excavated zones was helped in part by the deeper water application in the zone. Sodding of the excavated area may help stabilize the disturbed soil. Trees in excavated areas began strong regrowth, including compensatory shoot growth upon excavation. However, a modest level of tip-burn was evident.

Trenching implemented 17 years ago before tree planting at Orchard D has shown mixed results (Table 8 ). The trenched strips (noted as Exca. in the table) showed higher salinity than the zone ripped with the 36-inch shank, especially at depths below 1 $\mathrm{ft}$. This finding is a sharp contrast to the results from Orchard B shown earlier. The data also show that the excavated zone had salinity equal to or higher than salinity of the MTSCtreated zones and that the field soil moisture content of the excavated zone at $\mathrm{Hk}$ and Gs sites was greatly lower than the other zones (Table 8). One possible explanation is that permeability of the excavated soils has decreased over the 17-year period. Indeed, there are many cases where permeability of excavated soils have declined when subsoils affected by $\mathrm{Na}$ were brought to the surface (Miyamoto and Storey, 1995). In this case, a more realistic reason seems to be settling in the traffic zones, coupled with deep 
Table 7. The saturation water contents (SWC), soil salinity, and field moisture contents of soil samples collected from untreated (Control), ripped (Rip), and excavated (Exca.) strips at pecan Orchard B. ${ }^{\mathrm{z}}$

\begin{tabular}{|c|c|c|c|c|c|c|c|c|c|}
\hline \multirow{2}{*}{ Depth $(\mathrm{ft})^{\mathrm{y}}$} & \multirow[b]{2}{*}{ Texture } & \multicolumn{2}{|c|}{$\operatorname{SWC}(g / 100 g)^{y}$} & \multicolumn{3}{|c|}{ Salinity $\left(\mathrm{d} S \cdot \mathrm{m}^{-1}\right)^{\mathrm{y}}$} & \multicolumn{3}{|c|}{ Field moisture (g/100 g) } \\
\hline & & Control & Exca. & Control & Rip & Exca. & Control & $\operatorname{Rip}$ & Exca. \\
\hline \multicolumn{10}{|c|}{ Glendale silty clay (Gs), Site 19} \\
\hline $0-1$ & Silty clay & 63 & 45 & $2.5 \mathrm{a}^{\mathrm{x}}$ & $2.9 \mathrm{a}$ & $1.1 \mathrm{~b}$ & $13 \mathrm{a}$ & $12 \mathrm{a}$ & $11 \mathrm{a}$ \\
\hline $1-2$ & Silty clay & 70 & 41 & $6.0 \mathrm{a}$ & $4.5 \mathrm{~b}$ & $1.1 \mathrm{c}$ & $23 \mathrm{a}$ & $22 \mathrm{a}$ & $14 \mathrm{~b}$ \\
\hline $2-3$ & Silty clay & 68 & 47 & $6.9 \mathrm{a}$ & $6.2 \mathrm{~b}$ & $1.2 \mathrm{c}$ & $25 \mathrm{a}$ & $24 \mathrm{a}$ & $16 \mathrm{~b}$ \\
\hline $1-2$ & Silty clay & 69 & 36 & $6.9 \mathrm{a}$ & $4.0 \mathrm{~b}$ & $1.7 \mathrm{c}$ & $23 \mathrm{a}$ & $21 \mathrm{a}$ & $10 \mathrm{~b}$ \\
\hline $2-3$ & Silty clay & 77 & 35 & $7.4 \mathrm{a}$ & $5.4 \mathrm{~b}$ & $1.5 \mathrm{c}$ & $25 \mathrm{a}$ & $28 \mathrm{a}$ & $11 \mathrm{~b}$ \\
\hline
\end{tabular}

${ }^{\mathrm{z}}$ For description of Orchard B, refer to Table 2 .

${ }^{y} \mathrm{lft}=0.3048 \mathrm{~m}, \mathrm{lg} / \mathrm{l} 00 \mathrm{~g}=1 \%, \mathrm{ldS} \cdot \mathrm{m}^{-1}=1 \mathrm{mmho} / \mathrm{cm}$.

${ }^{x}$ Numbers in rows followed by the same letter are not significantly different via Duncan's multiple range test at $P \leq 0.05$.

"Results from Site 2 were similar to Site 16 and are omitted for simplicity.

Table 8. The saturation water contents (SWC), soil salinity, and field moisture contents of soil samples collected from untreated rows (control), excavated rows (Exca.), deep-ripped strips (Rip), and minimum-till shallow chiseled (MTSC) zones at pecan Orchard $D .^{z}$

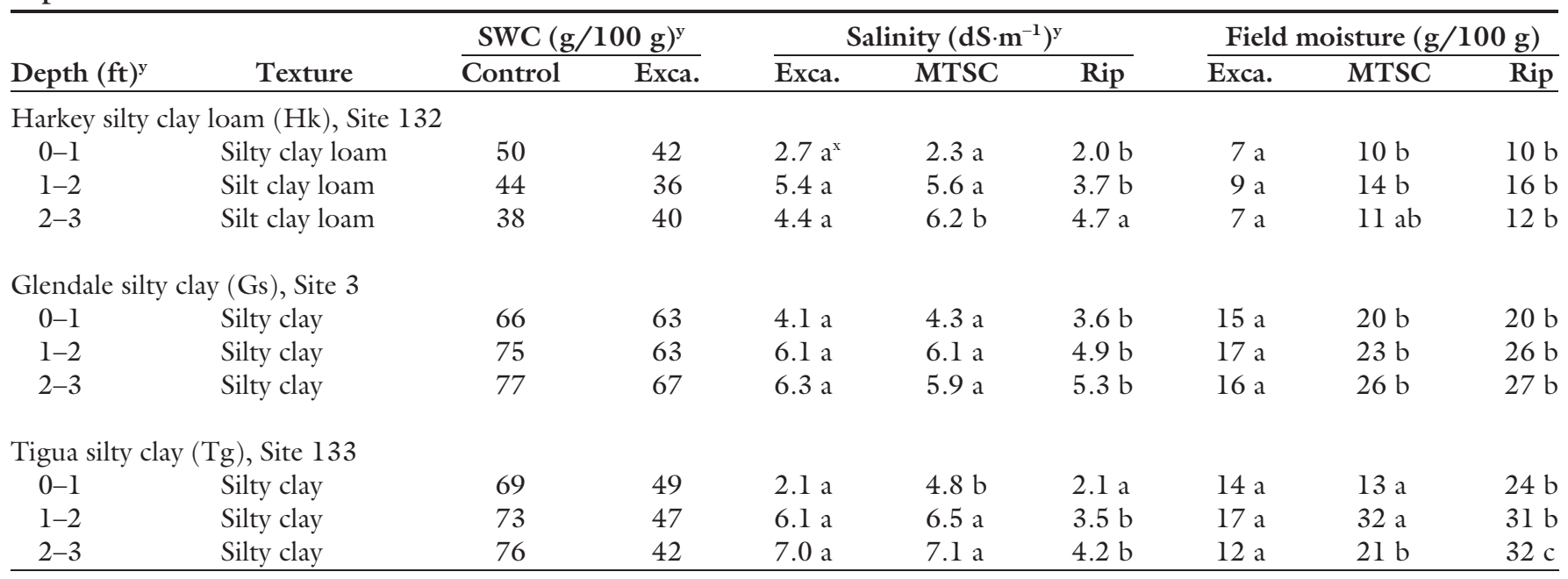

${ }^{\mathrm{z}}$ For description of Orchard D, refer to Table 2 .

${ }^{\mathrm{y}} \mathrm{l} \mathrm{ft}=0.3048 \mathrm{~m}, \mathrm{lg} / \mathrm{l} 00 \mathrm{~g}=1 \%, \mathrm{l} \mathrm{dS} \cdot \mathrm{m}^{-1}=1 \mathrm{mmho} / \mathrm{cm}$.

${ }^{x}$ Numbers in rows followed by the same letter are not significantly different via Duncan's multiple range test at $P \leq 0.05$.

ripping and premature cut-off of irrigation. A field observation indicated that the elevation of the tree row became higher by at least 1 inch over the traffic row where deep ripping was performed.

Overall assessment. This study indicates that salt leaching can be enhanced through modifying soil structure and/or texture of the clayey layer present above sandy subsoils, a unique feature of Torrifluvents in the study area. It is widely believed that soil compaction (which usually occurs at and near the soil surface) limits water infiltration and salt leaching. If this assessment is correct, decompaction of the surface soils with shallow chisels or cultivators alone should have alleviated water penetration and salt leaching problems. However, these methods were found to have limited value in soils with a thick clayey layer (Tables 4 and 5 ) although the field soil moisture was nearly equal to that from the ripped zone. Low permeability of the clay layer below the surface may have limited the downward movement of soil water and salt leaching. There are other observations, which seem to support this hypothesis. First, soil salinity tends to be higher with increasing thickness of clay layer (Tables 5-8). The most extensive leaching was observed when the clayey layer was modified to its full extent through profile modification (Table 7 ) or by deep ripping (Table 5 ).

It has been suggested that the presence of a high water table is the cause of soil salinization in the study area. Although the water table is indeed elevated ( 6 to $9 \mathrm{ft}$ from the ground surface) during summer months, no correlation was found between soil salinity and groundwater levels. The steady-state analysis of the upward capillary flow (e.g., Gardner, 1957) indicates that the upward flow becomes significant when the water table becomes shallower than 4 to $5 \mathrm{ft}$, but not below $6 \mathrm{ft}$. Nonetheless, the high water table probably affects the permeability of clay in the capillary fringe, but not of sandy subsoils, thus reducing salt leaching in clayey soil types.

The presence of roots has to be an important consideration in selecting the method to be used. Soil profile modification certainly offers an effective option in soils with deep clay subsoil, such as Saneli and Tigua series, but cuts off roots. Fortunately, pecan trees have remarkable ability to 
reestablish the root system. Pruning of roots helps develop multiple fine roots from the cut, which extend by 2 to $3 \mathrm{ft}$ per season (Miyamoto, 2010). Ripping is well suited for initial soil preparation (before planting) and in young orchards. Annual use in mature orchards certainly raises some concern over root lifting, reworking of ripped fields as well as its true effectiveness in reducing salt stress as a result of annual root cutting. Reworking of the ripped field involves disking and leveling, which is often more time-consuming than does ripping operation. The MTDC also has the problem of cutting roots although it does not lift the roots or rips the ground surface. It creates numerous soil structural cracks, which are needed for rapid transmission of soil water (e.g., Pandey, 1985), and sand application has shown to help maintain structural cracks and soil permeability. Sand mulch is also reported to reduce aggregate destruction associated with clean cultivation (Acharya and Abrol, 1976). It is unknown at present how long the effect of sand application may last beyond the 3-year experience. The annual use of minimum-till surface chisel, perhaps with sodding, may help maintain permeability and salt leaching. Additional years are needed to make assessment of longevity of chiseled and topdressed orchard floor.

In addition to soil texture and profile factors, irrigation practices seemed to have had a significant effect on salt leaching. Soil salinity of untreated zones of Glendale soil series in Orchard E (Table 5) is, for example, lower than that observed for the similar soil at Orchard D (Table 5) although orchard $\mathrm{E}$ has been irrigated with water of higher salinity. This orchard has been irrigated more often and practiced late season irrigation. This study also indicates that flood irrigation has to have the leveled floor for uniform salt leaching. A field study conducted in deep loamy sand using large transplanted trees shows that water uptake was greatest near the tree trunk (Sorensen and Jones, 1999), presumably because the root density of the transplanted trees was highest near the trunk. Root pruning with ripper or subsoiling shanks is likely to yield high root densities along the chiseling lines. It may be advantageous to have the ground slightly tilted toward the shank path if it can be managed.

\section{Literature cited}

Acharya, C.L. and I.P. Abrol. 1976. Effect of river sand on the permeability of a sodic soil. J. Indian Soc. Soil Sci. 24:245-252.

Folorunso, O.A., D.F. Ralston, T. Prichard, and D.T. Louie. 1992. Cover crops lower soil surface strength, and may improve soil permeability. Calif. Agr. 46(6):26-27.

Gardner, W.R. 1957. Some steady-state solutions of the unsaturated moisture flow equation with application to evaporation from a water table. Soil Sci. 85:228-232.

Håkansson, I. and R.C. Reeder. 1994. Subsoil compaction by vehicles with high axle load-extent, persistence and crop response. Soil Tillage Res. 29:277-291.

Helmers, S. and S. Miyamoto. 1990. Mechanical and chemical practices for reducing salinity in pecan orchards. Proc. Natl. Irr. Conf. Amer. Soc. Agr. Eng. p. 374-377.

Kaddah, M.T. 1976. Subsoil chiseling and slip plowing effects on soul properties and wheat grown on a stratified fine sandy soil. Agron. J. 68:30-39.

Kallestad, J.C., T.W. Sammis, J.G. Mexal, and V. Gutschick. 2007. The impact of prolonged flood-irrigation on leaf gas exchange in mature pecans in an orchard setting. Intl. J. Plant Production 1:163-178.

Little, T.M. and F.J. Hills. 1975. Statistical method in agricultural research. Univ. of California, Davis.

Miyamoto, S. 1983. Consumptive use of irrigated pecans. J. Amer. Hort. Sci. 108: 676-681.

Miyamoto, S. 1990. A model to estimate salt accumulation and crop yields in surfaceirrigated orchards. Proc. Natl. Irr. Conf. Amer. Soc. Agr. Eng. p. 384-389.

Miyamoto, S. 2002. Guidelines for developing soil and water management programs: Irrigated pecans. Texas Water Resources Inst. TR-188.

Miyamoto, S. 2010. Salt leaching in pecan orchards of the Southwest. Pecan South 43(5):28-36.

Miyamoto, S. and I. Cruz. 1986. Spatial variability and soil sampling for salinity and sodicity appraisal in surface-irrigated orchards. Soil Sci. Soc. Amer. J. 50:10201026.

Miyamoto, S. and I. Cruz. 1987. Spatial variability of soil salinity in furrow-irrigated torrifluvents. Soil Sci. Soc. Amer. J. 51:1019-1025.

Miyamoto, S., G.R. Gobran, and K. Piela. 1985. Salt effects on seedling growth and ion uptake of three pecan rootstock cultivars. Agron. J. 77:383-388.

Miyamoto, S., T. Riley, G. Gobran, and J. Petticrew. 1986. Effects of saline water irrigation on soil salinity, pecan tree growth and nut production. Irrig. Sci. 7:83-95.

Miyamoto, S. and J.B. Storey. 1995. Soil management in irrigated pecan orchards in the Southwestern U.S. HortTechnology 5:219-222.

Pandey, R.S. 1985. Effect of cracks on infiltration behavior in salt-affected soils. J. Indian Soc. Soil Sci. 33:137-140.

Picchioni, G.A., H. Karaca, L.G. Boyse, B.D. McCaslin, and E.A. Herrera. 2000. Salinity, boron, and irrigated pecan productivity along New Mexico's Rio Grande Basin. J. Environ. Qual. 29:955-963.

Prichard, T.L., W.K. Asai, and L.C. Hendricks. 1990. Orchard vegetation management: Effects on water use and soil characteristics. Western Pecan Conf. Proc. p. 56-59.

Rhoades, J.D. 1974. Drainage for salinity control, p. 433-470. In: J. van Schilfgaarde (ed.). Drainage for agriculture. Amer. Soc. Agron., Madison, WI.

Rhoades, R.J. and S. Miyamoto. 1990. Testing soils for salinity and sodicity, $\mathrm{p}$. 299-336. In: Westerman, R.L. (ed.). Soil testing and plant analysis. 3rd ed. Soil Sci. Soc. Amer. Book Ser. 3. Soil Sci. Soc. Amer., Madison, WI.

Robinson, F.E. and J.N. Luthin. 1968. Slip plowing in nonstratified clay. Calif. Agr. 22(11):8-9.

Shafiq, M., A. Hassan, and S. Ahmad. 1994. Soil physical properties as influenced by induced compaction under laboratory and field conditions. Soil Tillage Res. 29:13-22.

Sillon, J.F., G. Richard, and I. Cousin. 2003. Tillage and traffic effects on soil hydraulic properties and evaporation. Geoderma 11:29-46.

Sorensen, R.B. and T.L. Jones. 1999. Soil water uptake patterns of pecan trees grown in coarse gravelly soils. HortTechnology 9:402-408.

U.S. Department of Agriculture and Texas Agricultural Experiment Station. 1971. Soil survey of El Paso County. U.S. Dept. Agr. and Texas Agr. Expt. Sta., El Paso, TX.

Wildman, W.E., W.L. Peacock, A.M. Wildman, G.G. Goble, J.E. Pehrson, and N.V. O'Connell. 1988. Soluble calcium compounds may aid low-volume water application. Calif. Agr. 42(6):7-8. 